\title{
Studies on Cercariae from Kuwait Bay. XI. Description and Surface Topography of Cercaria kuwaitae XI sp.n. (Digenea: Echinostomatidae)
}

\author{
J Abdul-Salam ${ }^{+}$, BS Sreelatha
}

\author{
Department of Biological Sciences, Kuwait University, P. O. Box 5969, Safat 13060, Kuwait
}

\begin{abstract}
A new echinostome cercaria, Cercaria kuwaitae XI sp.n., from the prosobranch gastropod Cerithidea cingulata (Gmelin) from Kuwait Bay is described. The new cercaria is characterized by 23 collar spines and primary excretory tubules with distinct diverticula. The cercaria encysts in the snail host and is similar to those of Acanthoparyphium sp. The surface topography of the redia, cercaria and metacercarial cyst wall is studied by scanning electron microscopy. This is the first echinostome cercaria to be recorded in a gastropod from the Arabian Gulf region.
\end{abstract}

Key words: Digenea - Cercaria kuwaitae XI sp.n. - Acanthoparyphium sp. - ultrastructure - Cerithidea cingulata Kuwait Bay

Adult trematodes of the family Echinostomatidae Looss, 1902 are generally parasitic in the digestive tract of aquatic birds. Larval stages develop in the hepatopancreas of prosobranch snails and encyst as metacercariae in the same snail or in lamellibranchs.

The present study describes a new larval echinostome, similar to those of Acanthoparyphium sp., from the gastropod Cerithidea cingulata from Kuwait Bay. The surface topography of the redia, cercaria and metacercarial cyst wall is studied by scanning electron microscopy (SEM).

\section{MATERIALS AND METHODS}

Naturally infected specimens of Cerithidea cingulata (Gmelin) were collected from Sulaibikhat mud flat, southern Kuwait Bay, during FebruaryJune 1995. To obtain freshly emerged cercariae, snails were individually isolated in small vials containing filtered seawater and left at room temperature until examined under a dissecting microscope. Rediae were obtained by dissecting infected snails. Metacercarial cysts were recovered from tissue of snails both infected and uninfected by parthenogenetic generations. Larval stages were studied live, unstained or vitally stained with $5 \%$ neutral red, and also after fixation in hot acetic acid-formalin-

${ }^{+}$Corresponding author. Fax: (965) 2425912. E-mail: research@kfas.org.kw.

Received 8 December 1998

Accepted 30 June 1999 alcohol (AFA) and staining in acetocarmine. Measurements are in micrometres, the range with the mean in parentheses, and were taken from 20 vitally stained refrigerated specimens. Figures were drawn with the aid of a camera lucida from vitally stained specimens.

For SEM, living larval stages were fixed in a solution containing $4 \%$ formaldehyde and $1 \%$ glutaraldehyde in $0.1 \mathrm{~m}$ phosphate buffer $(\mathrm{pH} 7.2)$ at $4^{\circ} \mathrm{C}$. Following the appropriate buffer wash, the specimens were post-fixed in $1 \%$ osmium tetroxide in the same buffer for $5 \mathrm{~min}$ at $4^{\circ} \mathrm{C}$, dehydrated in a series of anhydrous acetone and critical-point dried. The specimens were coated with gold and then examined in a Jeol JSM-6300 scanning electron microscope.

The nomenclature for the new cercaria follows the system of Cable (1956) based on Sewell (1922).

\section{RESULTS}

\section{Cercaria kuwaitae XI sp.n.}

Figs 1-13

Host: Cerithidea cingulata (Gmelin, 1791).

Locality: Sulaibikhat, Kuwait Bay.

Habitat: muddy substrate.

Infection site: rediae in hepatopancreas and gonad; metacercariae in muscle tissue of snail host.

Prevalence of infection: rediae 26 of 1,651 snails (1.6\%); metacercariae 371 of 2,537 snails (14.6\%).

Specimens deposited: Helminth Collection, Department of Biological Sciences, Kuwait University, (Accession No. KUHC-C-EC1.).

Description: Cercaria (Figs 1-A to C): echinostome cercaria, 380-460 (425) long, 125-200 (171) wide at about mid-level. Distinct collar at pharyngeal level, bearing 23 spines in single uninterrupted row; 
spines 8-12 (10) long, 2-3 (2.5) wide. Tegument aspinose; ciliated papillae (setae) occur anteriorly and laterally. Tail simple, without fin-fold, attached subterminally, 250-400 (352) long, 30-50 (39) wide at base. Oral sucker subterminal, 40-55 (52) in diameter; ventral sucker, about $2 / 3$ of body length from anterior end, 50-83 (76) in diameter. Prepharynx 1325 (23) long; pharynx 23-30 (25) long; oesophagus 93-143 (115) long, bifurcating just anterior to ventral sucker; caeca narrow, extending nearly to posterior end of body. Penetration glands of two types; one pair at posterior rim of oral sucker, two pairs flank oesophagus; gland ducts open anterior to oral sucker. Cystogenous cells throughout body, with opaque, granular cytoplasm. Excretory vesicle oval, thin-walled; with short median anterior stem which divides into two voluminous lateral primary excretory tubules with distinct diverticula between ventral sucker and pharynx, filled with excretory concretions; tubules reflex at oral sucker level, receiving anterior and posterior collecting tubules at ventral sucker level. Caudal excretory duct extending into tail, bifurcating and opening laterally close to base. Flame-cell formula $2[(6+5+5)+(6+5+5)]=$ 64 . Genital primordia in form of longitudinal mass dorsal to ventral sucker.

Behaviour: cercaria swims with its body contracted into spherical mass and tail lashing vigorously. It rests on bottom of container and creeps by alternate use of suckers. It does not encyst outside snail host.

Redia (Fig. 1-D): mature redia sac-like, yellowish, 1,050-2,050 (1,454) long, 250-350 (301) wide, with distinct collar and two ambulatory buds (procruscula) at $2 / 3$ of body from anterior extremity. Pharynx 35-50 (43) long, 33-48 (41) wide; gut short, 250-290 (268) long. Contains immature cercariae and germ balls in various stages of development. Mature cercariae are found exclusively in host tissue.

Metacercaria (Fig. 1-E): metacercarial cyst occurs in snails, both those infected and uninfected by parthenogenetic generations; they are attached to mantle and to muscles on inner surface of operculum. Cyst round and transparent, 255-290 (274) in diameter measured from outer wall and 207-260 (235) in diameter from the inner wall. Metacercaria is folded inside cyst. Living metacercariae are characterized by extension and contraction of body and movement of concretions in excretory diverticula.

\section{SEM observations}

Redia: SEM observations of rediae showed tapered anterior and rounded posterior ends, with two conical ambulatory buds at junction of second and last thirds of body and mouth at anterior tip (Fig. 2). Mouth surrounded by lip-like rim and attached to protrusible, cylindrical neck (Fig. 3). Tegumental surface throughout body displays transverse folds densely covered with microvilli (Figs 4, 5). Small globules ooze from surface in microscopical preparations (Fig. 5). Distinct collar separates neck from rest of body. Just posterior to collar is situated birth papilla with folded outer surface (Figs 2,3). Two types of papillae, with short rigid or long flexible cilia, are concentrated on rim of mouth (Fig. 4). Papillae with long cilia are sparsely scattered throughout body (Fig. 5).

Cercaria: oval body with prominent suckers and tapered tail (Fig. 6). Tegumental surface of body and tail folded into transverse rings (Figs 6,7 ) densely covered with short microvilli and minute spherical bodies (Fig. 8). Papillae with short, rigid or long, flexible cilia are concentrated around oral sucker (Fig. 9). Both types of cilia protrude from tegumental swellings (Figs 8, 9). Rows of papillae with long cilia are disposed bilaterally on lateral and mid-dorsal aspects of body (Fig. 7). Aciliated, dome-shaped papillae are restricted to the inner and outer surfaces of ventral sucker (Fig. 10). Tail stem bears rows of short stiff cilia, each protruding from flat tegumental collar (Fig. 11).

Metacercarial cyst wall: cyst wall with smooth outer layer (Fig. 12) intermingled with host tissue at host-cyst attachment site (Fig. 13).

\section{DISCUSSION}

The genus Acanthoparyphium was established by Dietz (1909) with A. phoenicopteri (Lühe, 1898) as the type-species. Tubangui (1933) and Yamashita (1937) placed Acanthoparyphium in the family Echinostomatidae Looss, 1902, subfamily Himasthlinae Odhner, 1910. Yamaguti (1958) transferred the genus to the subfamily Echinstomatinae and gave a generic diagnosis based primarily on the number of collar spines. C. kuwaitae XI possesses 23 collar spines in a single row and primary excretory tubules with distinct diverticula. These are characteristic features of Acanthoparyphium cercariae. Marine snails, predominantly of the family Potamididae, serve as the first and second intermediate hosts for Acanthoparyphium sp. (Table). The new cercaria is morphologically similar to the cercaria of Acanthoparyphium sp. Yamaguti (1934), A. paracharadrii Velasquez, 1964 and $A$. spinulosum Johnston, 1917, and to C. caribbea II Cable, 1956, C. bengalensis II Mani and Rao, 1993, C. queenslandae I Cannon, 1978 and C. yamagutii Ito, 1957. However, discrepancies in the number and arrangement of the flame-cells among most of these cercariae exist due to the obstruction of the excretory system by dense cystogenous glands and concretions in the collecting tubules. In $A$. spinulosum, Bearup (1960) counted up to 24 flame- 
A

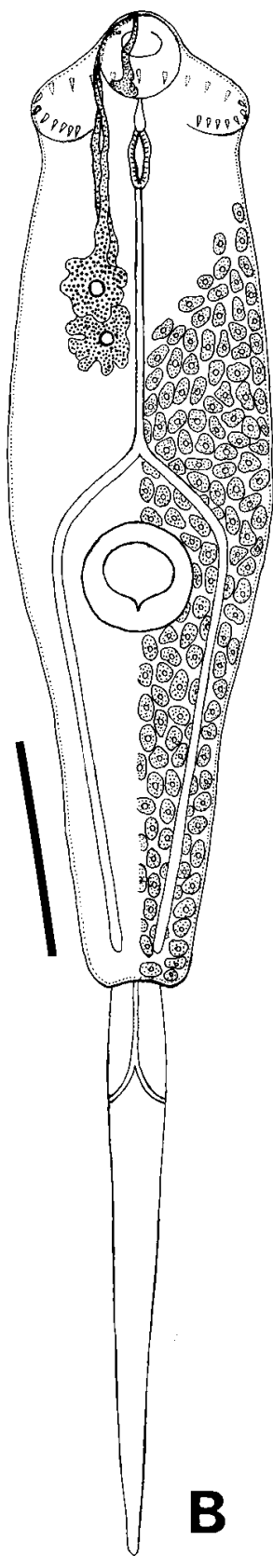

C

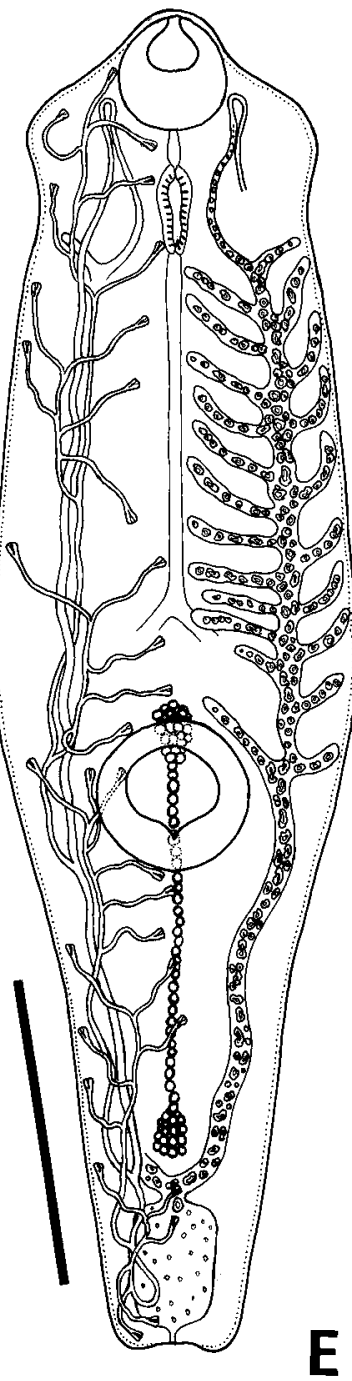

$\mathbf{E}$
D

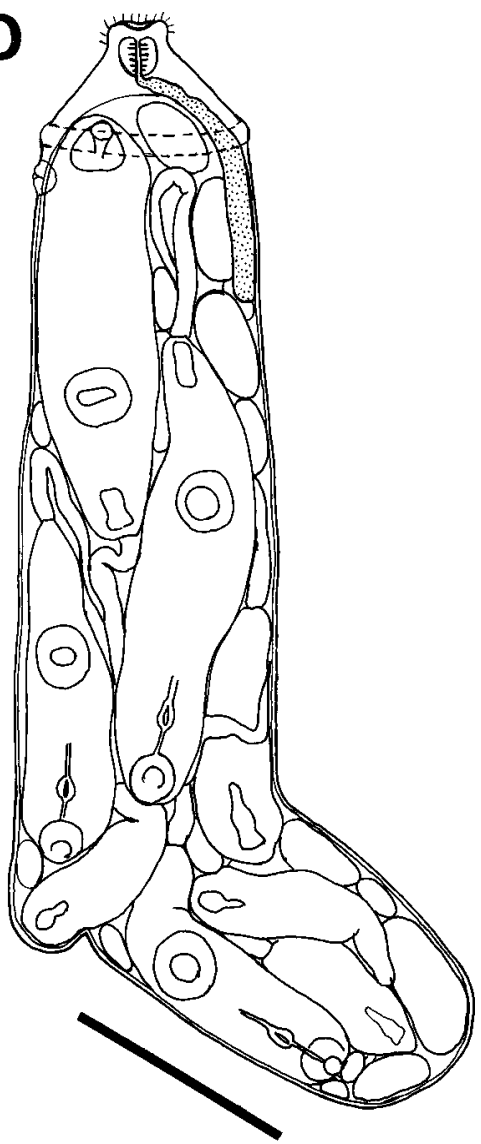

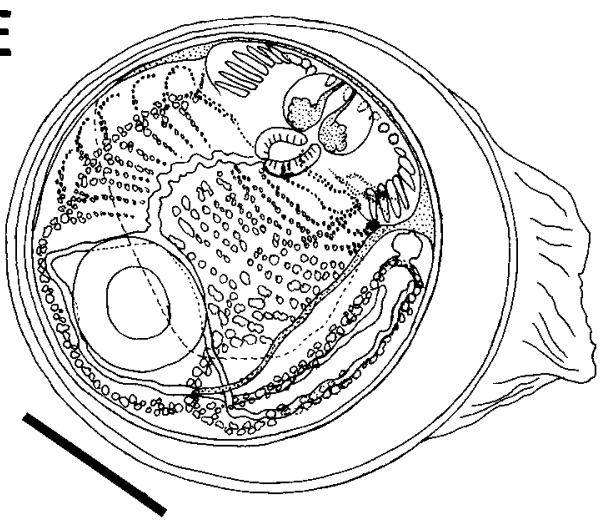

Fig. 1: Cercaria kuwaitae XI sp.n. A: cercaria, ventral view, bar $=0.1 \mathrm{~mm}$; B: collar spine of cercaria, bar $=0.05 \mathrm{~mm}$; C: excretory system of cercaria, bar $=0.1 \mathrm{~mm}$; D: redia, bar $=0.25 \mathrm{~mm}$; E: encysted metacercaria, bar $=0.1 \mathrm{~mm}$. 

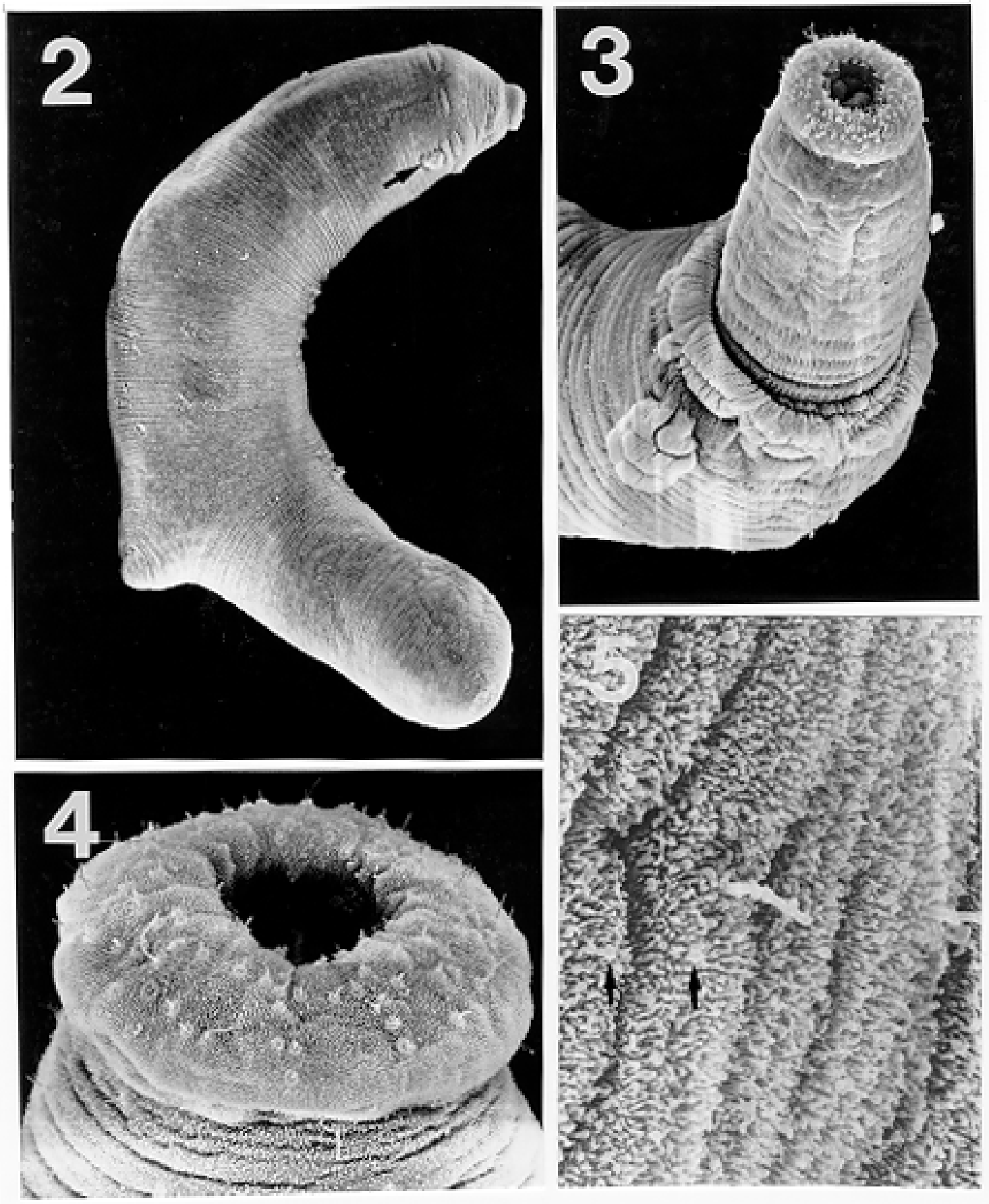

Scanning electron micrographs of Cercaria kuwaitae XI sp.n., mature redia. Fig. 2: entire redia showing mouth, collar and birth papilla (arrow) at anterior end, and ambulatory bud at posterior third of the body. The tegumental surface displays transverse ridges, bar $=150 \mu \mathrm{m}$. Fig. 3: anterior region of the body showing extended neck, mouth surrounded by ciliated papillae, collar, and birth papilla, bar $=30 \mu \mathrm{m}$. Fig. 4: anterior end of the body showing mouth surrounded by papillae with short stiff and long flexible cilia each protruding from a tegumental collar, bar $=15 \mu \mathrm{m}$. Fig. 5: tegumental surface of an area immediately posterior to the body collar showing microvilli and ciliated papilla. Note small globules oozing from the surface (arrows), bar $=3 \mu \mathrm{m}$. 

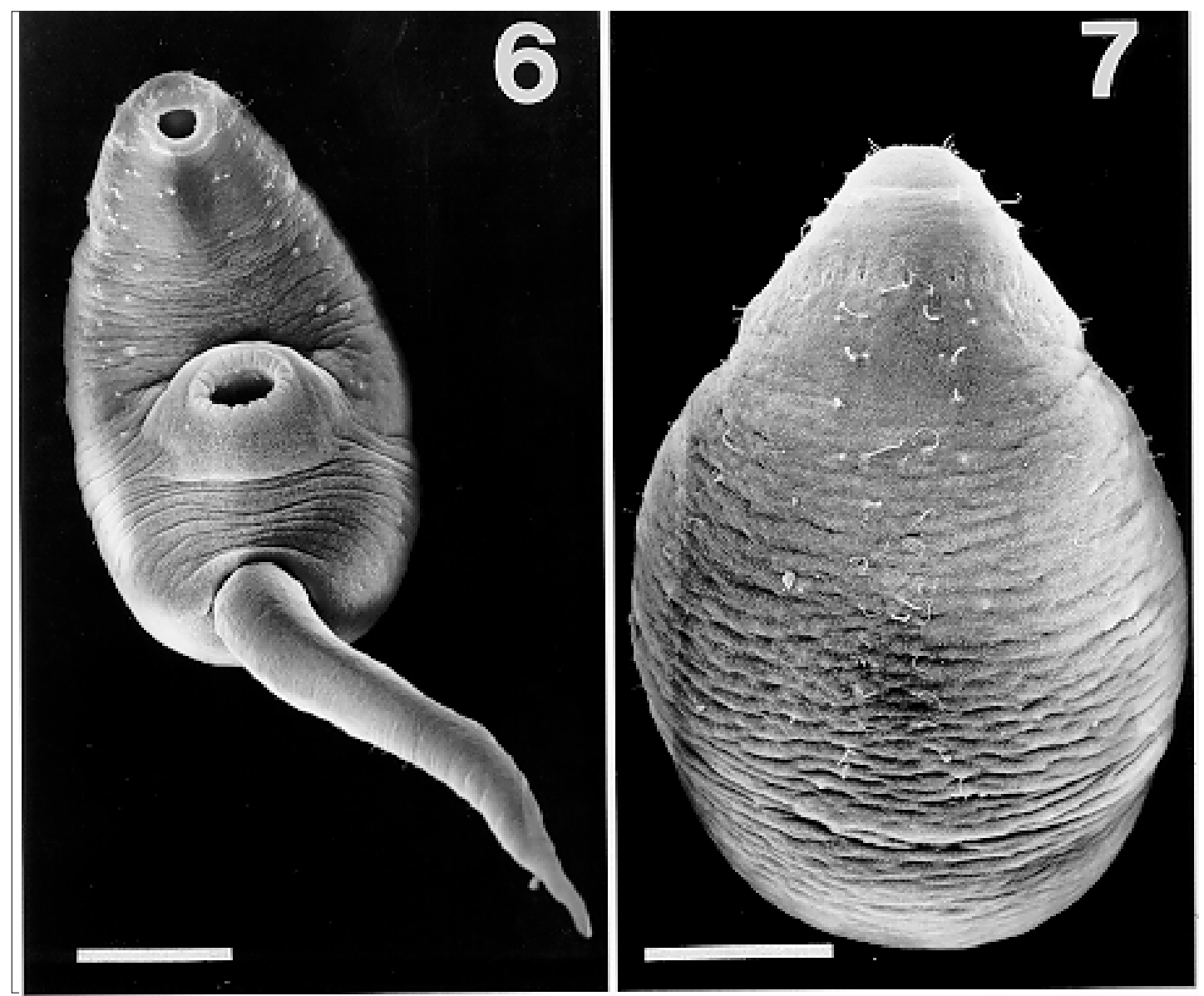

Scanning electron micrographs of Cercaria kuwaitae XI sp.n., cercaria. Fig. 6: ventral view of entire cercaria showing oral and ventral suckers, and tapered tail. The tegumental surface shows transverse annulations, and concentration of papillae around the oral sucker and on anterio-lateral aspects of the body, bar $=40 \mu \mathrm{m}$. Fig. 7: dorsal view the body showing collar spine sockets at anterior region and longitudinal rows of ciliated papillae on the medial and lateral aspects, bar $=30 \mu \mathrm{m}$.

\section{TABLE}

Marine snails reported as intermediate hosts for Acanthoparyphium sp.

\begin{tabular}{|c|c|c|}
\hline Snail & Country & Reference \\
\hline$\overline{\text { Batillaria mutiformis (Lischke) }})^{a}$ & Japan & Yamaguti 1934 \\
\hline Cerithidea californica Haldeman ${ }^{a}$ & United States & $\begin{array}{l}\text { Maxon \& Pequegnat } 1949 \\
\text { Martin \& Adams } 1961\end{array}$ \\
\hline Cerithidea cingulata Gmelin & Japan & Ito 1957 \\
\hline Cerithidea cingulata Gmelin & India & Mani \& Rao 1993 \\
\hline Cerithidea cingulata $\mathrm{Gmelin}^{a}$ & Kuwait & Present study \\
\hline Cerithidea costata de Costa & Puerto Rico & Cable 1956 \\
\hline Cerithidea fluviatilis (Potiez \& Michaud) & Japan & Ito 1957 \\
\hline Cerithidea largillierti Philippi & Japan & Ito 1957 \\
\hline Cerithium moniliferum $\mathrm{Kiener}^{a}$ & Australia & Cannon 1978 \\
\hline Cerithium ornata Adams ${ }^{a}$ & Philippines & Velasquez 1964 \\
\hline Pyrazus australis Quoy \& Gaimard & Australia & Bearup 1960 \\
\hline Tympanotonus microptera (Kiener) & Japan & Ito 1957 \\
\hline
\end{tabular}

$a$ : serves as first and second intermediate host. 

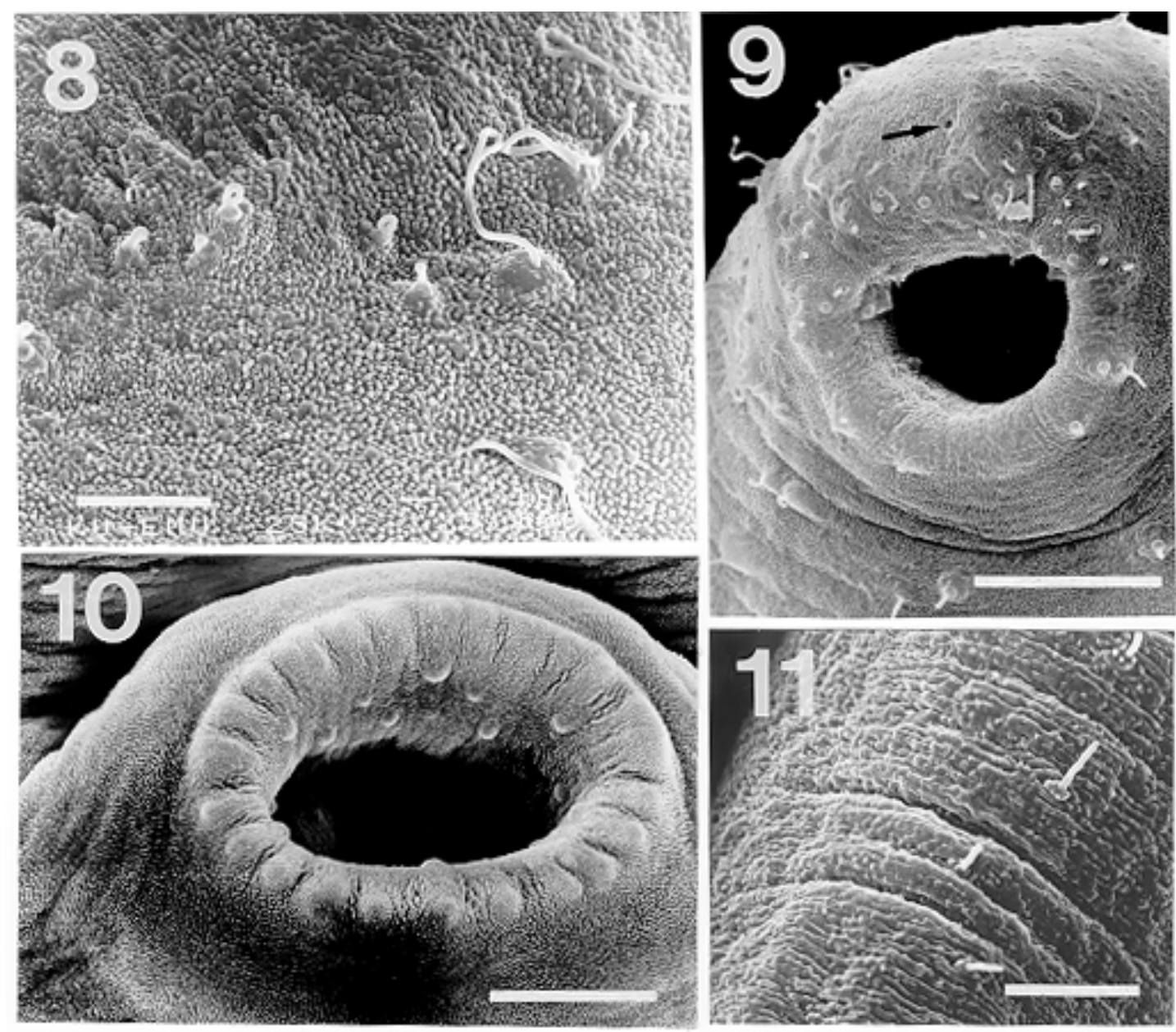

Scanning electron micrographs of Cercaria kuwaitae XI sp.n., cercaria. Fig. 8: tegumental surface of an area dorsal to the oral sucker, the surface is covered with microvilli and minute spherical bodies, and cilia varying in length each protruding from a tegumental swelling, bar $=4 \mu \mathrm{m}$. Fig. 9: sub-terminal region of the body showing oral sucker fringed by papillae with flexible cilia of different length and gland duct openings at the anterior border (arrow), bar $=10 \mu \mathrm{m}$. Fig. 10: mid-ventral region the body showing raised ventral sucker encircled by domed papillae, bar $=10 \mu \mathrm{m}$. Fig. 11 : tail stem showing row of short stiff cilia each protruding from a tegumental collar, bar $=4 \mu \mathrm{m}$.

cells on one side of the body, while Martin and Adams (1961) reported for the same species 32 flame-cells arranged in pairs; in A. paracharadrii Velasquez (1964) counted 30-32 flame-cells; and in C. bengalensis II and C. queenslandae I, Mani and Rao (1993) and Cannon (1978), respectively, were not able to determine the number. Ito (1957) presented a complete flame-cell formula for $C$. yamagutii which differs in numbers and arrangement from the new cercaria. $C$. bengalensis II from C. cingulata in India differs from the new cercaria in having spinose tegument and 12 large penetration glands on either side of the oesophagus.

The general features of the surface morphology of the redia and metacercarial cyst wall of $C$. kuwaitae XI are similar to those of other digeneans for which surface features have been described (Køie 1971, Irwin et al. 1978, Rees 1980, Fried \& Awatramani 1992, Nollen 1992). Like rediae of other digeneans, sensory papillae with short and long cilia were abundant around the mouth of the redia of $C$. kuwaitae XI. However, spherical bodies reported around the mouth of rediae of most other digeneans were not detected in the new redia. Krejci and Fried (1994) utilized SEM to distinguish rediae and metacercarial cysts of Echinostoma caproni Richard, 1964 and E. trivolvis (Cort, 1914) Kanev, 1985 . The comparison was primarily based on differences in the types and numbers of ciliated sensory papillae around the mouth of the rediae and 

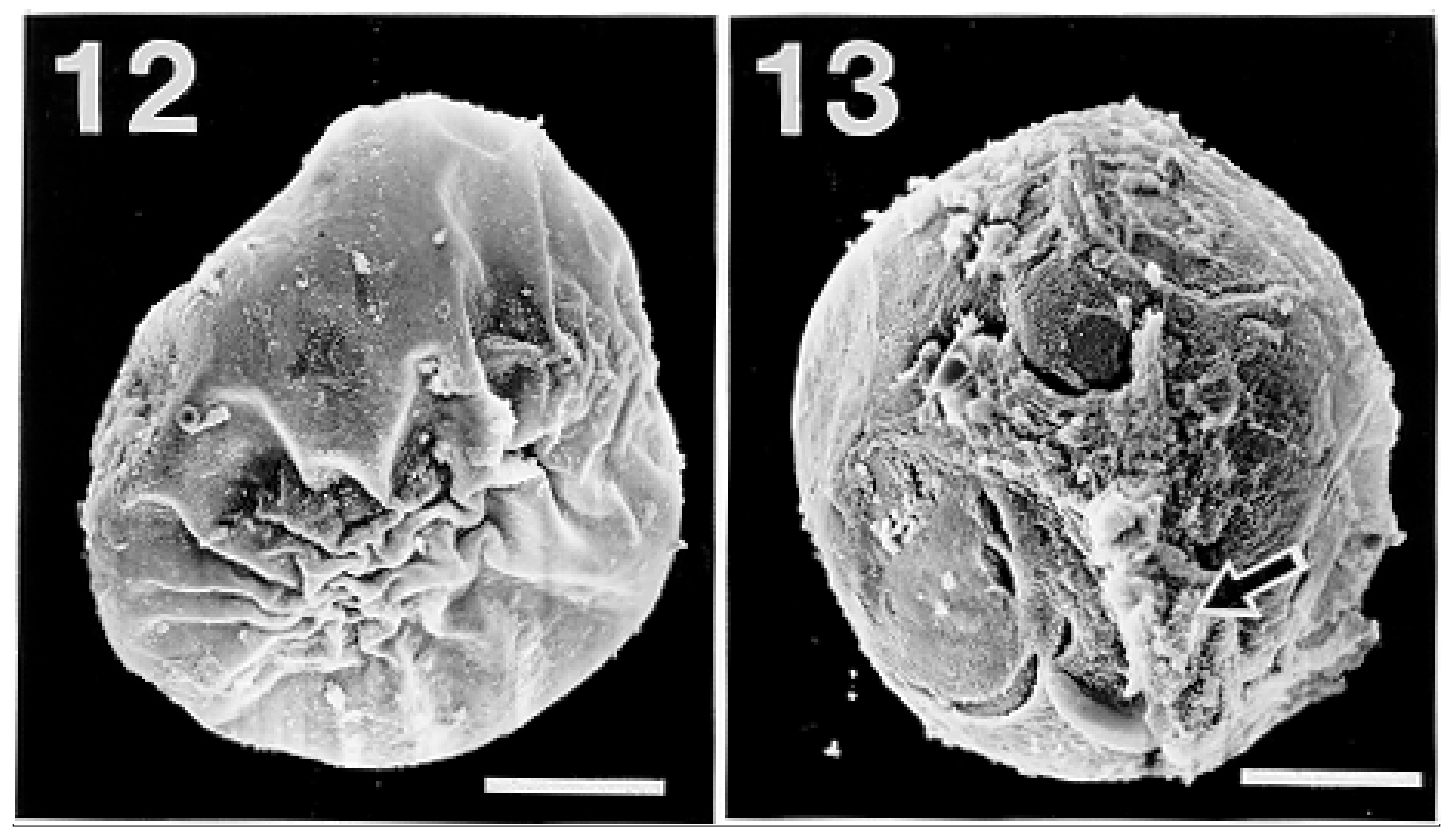

Scanning electron micrographs of Cercaria kuwaitae XI sp.n., metacercarial cyst. Fig. 12: intact cyst, bar $=50 \mu \mathrm{m}$. Fig. 13: host-cyst attachment site (arrow), bar $=50 \mu \mathrm{m}$.

variations in the texture of the metacercarial cyst wall. Like other echinostome cercariae, the new cercaria showed prominent collar spine sockets, ciliated papillae on the body and tail, and domed papillae on the ventral sucker (Našincová 1986, Køie 1987, Krejci \& Fried 1994). Ultrastructural observations have shown that ciliated papillae on the tegument of digeneans are actually bulbous extensions of nervous processes (Smyth \& Halton 1983). The site-specificity of these structures suggests that they function as mechanoreceptors. Spherical bodies densely covering the tegumental surface of the present cercaria are most likely chemicals produced by the cystogenous glands which may be used for the synthesis of the metacercarial wall.

Although C. kuwaitae XI was found encysted in the snail Cerithidea cingulata, other invertebrates in the Kuwait Bay, particularly lamellibranchs, may also serve as second intermediate host. The new cercaria almost certainly develops into a species of Acanthoparyphium in charadriid birds which are abundant in the Bay.

\section{ACKNOWLEDGEMENT}

To the staff of the Electron Microscopy Unit, Faculty of Science, Kuwait University for their help and guidance with the SEM aspects of the study.

\section{REFERENCES}

Bearup AJ 1960. Life history of Acanthoparyphium spinulosum Johnston, 1917 (Trematoda: Echinos- tomatidae). Aust J Zool 8: 217-225.

Cable RM 1956. Marine cercariae of Puerto Rico. Scientific survey of Porto Rico and the Virgin Islands. $N Y$ Acad Sci 16: 491-577.

Cannon LRG 1978. Marine cercariae from the gastropod Cerithium moniliferum Kiener at Heron Island, Great Barrier Reef. Proc R Soc Qd 89: 45-57.

Dietz E 1909. Die Echinostomiden der Vögel Zool Anz 34: 180-192.

Fried B, Awatramani R 1992. Light and scanning electron microscopical observations of the daughter-rediae of Echinostoma trivolvis (Trematoda). Parasitol Res 78: 257-259.

Irwin SWB, Threadgold LT, Howard NM 1978. Cryptocotyle lingua (Creplin) (Digenea: Heterophyidae): observations on the morphology of the rediae, with special reference to the birth papilla and release of cercariae. Parasitology 78: 193-199.

Ito J 1957. Studies on the brackish water cercariae in Japan. III. Three new echinostome cercariae in Tokyo Bay, with a list of Japanese echinostome cercariae (Trematoda). Jap J Med Sci Biol 10: 439-453.

Køie M 1971. On the histochemistry and ultrastructure of the redia of Neophasis lageniformis (Lebour, 1910) (Trematoda: Acanthocolpidae). Ophelia 9: 113-143.

Køie M 1987. Scanning electron microscopy of rediae, cercariae, metacercariae and adults of Mesorchis denticulatus (Rudolphi, 1802) (Trematoda, Echinostomatidae). Parasitol Res 73: 50-56.

Krejci KG, Fried B 1994. Light and scanning electron microscopic observations of the eggs, daughter rediae, cercariae, and encysted metacercariae of Echinostoma trivolvis and E. caproni. Parasitol Res 
80: 42-47.

Mani G, Rao KH 1993. Studies on Indian marine cercariae: two new echinostome cercariae. J Helminthol Soc Wash 60: 250-255.

Martin WE, Adams JE 1961. Life cycle of Acanthoparyphium spinulosum Johnston, 1917 (Echinostomatidae: Trematoda). J Parasitol 47: 777 782.

Maxon MG, Pequegnat WE 1949. Cercariae from Upper Newport Bay. J Entomol Zool 41: 30-55.

Našincová V 1986. Contribution to the distribution and the life history of Echinostoma revolutum (Trematoda) in Central Europe. Vest $\breve{c s}$ Spole $\check{c}$ zool 50: 7080.

Nollen PM 1992. A comparison of the surface features of Philophthalmus megalurus and Philophthalmus gralli rediae by scanning electron microscopy. $J$ Parasitol 78: 360-364.

Rees G 1980. Surface ultrastructure of the redia of Parorchis acanthus Nicoll (Digenea: Philophthalmidae). Z Parasitenkd 63: 33-46.

Sewell RBS 1922. Cercariae indicae. Indian J Med Res
10: $1-370$.

Smyth JD, Halton DW 1983. The Physiology of Trematodes, 2nd ed., Cambridge University Press, Cambridge, $446 \mathrm{pp}$.

Tubangui S 1933. Trematode parasites of Philippine vertebrates. VI. Descriptions of new species and classification. Phil J Sci 52: 167-197.

Velasquez CC 1964. Life history of Acanthoparyphium paracharadrii sp. n. (Trematoda: Echinostomatidae). J Parasitol 50: 261-265.

Yamaguti S 1934. Studies on the helminth fauna of Japan. Part. 3. Avian trematodes, II. Jap J Zool 5: 543583.

Yamaguti S 1958. Systema helminthum. Vol. I. The Digenetic Trematodes of Vertebrates. Parts I and II, Interscience Publishers, London and New York, 1575 pp.

Yamashita J 1937. Studies on the Echinostomatidae. Part II. A list of the family Echinostomatidae, trematode parasites of reptiles, birds and mammals, arranged systematically. Trans Sapporo Nat Hist Soc 5: 8295. 